\title{
The intersection between being a nurse and being a therapist in Mental Health
}

\author{
A interseção entre ser enfermeiro e ser terapeuta em saúde mental \\ La intersección entre ser enfermero y ser terapeuta de Salud Mental
}

Andréa Damiana da Silva Elias'
ORCID: 0000-0001-9143-4450

Cláudia Mara de Melo Tavares'

ORCID: 0000-0002-8416-6272

Marcela Pimenta Muniz'

ORCID: 0000-0002-8615-7513

'Universidade Federal Fluminense. Niterói, Rio de Janeiro, Brazil.

How to cite this article:

Elias ADS, Tavares CMM, Muniz MP. The intersection between being a nurse and being a therapist in Mental Health.

Rev Bras Enferm. 2020;73(1):e20180134. doi: http://dx.doi.org/10.1590/0034-7167-2018-0134

\section{Corresponding Author:}

Andréa Damiana da Silva Elias

E-mail: andreadamiana@gmail.com

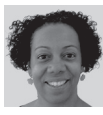

EDITOR IN CHIEF: Antonio José de Almeida Filho

Submission: 04-30-2018 Approval: 06-21-2018

\section{ABSTRACT}

Objective: to discuss the intersection between being a nurse/being a therapist in the mental health field. Method: exploratory, qualitative study based on a self-report interview conducted with ten nurses from a psychiatric hospital in Rio de Janeiro between June and July 2017. Data were analyzed in the light of Travelbee's theory. Results: Nurses consider themselves therapists because of actions performed in mental health care practice, despite the theoretical fragmentation of interpersonal relationships identified in the distance from the promotion of self-knowledge, which is an essential element in the psychotherapeutic process. Final considerations: the strong relationship between being and doing in nursing stands out and favors the development of satisfactory therapeutic relationships with the hospitalized person.

Descriptors: Nurse's Role; Mental Health; Therapeutics; Psychiatric Nursing; Psychiatric Hospitals.

\section{RESUMO}

Objetivo: discutir a interseção do ser enfermeiro/ser terapeuta no campo da saúde mental. Método: pesquisa exploratória, qualitativa, pautada na entrevista de autorrelato desenvolvida com dez enfermeiras de um hospital psiquiátrico do Rio de Janeiro entre junho e julho de 2017. Os dados foram analisados à luz da teoria de Travelbee. Resultados: As enfermeiras se consideram terapeutas em função das ações desenvolvidas na prática de cuidados em Saúde Mental, apesar da fragmentação teórica do relacionamento interpessoal identificada no distanciamento da promoção de autoconhecimento, que é elemento imprescindível no processo psicoterapêutico. Considerações finais: A forte relação entre ser e fazer da enfermagem se destaca e favorece o desenvolvimento de relações terapêuticas satisfatórias com a pessoa internada.

Descritores: Papel do Profissional de Enfermagem; Saúde Mental; Terapêutica; Enfermagem Psiquiátrica; Hospitais Psiquiátricos.

\section{RESUMEN}

Objetivo: discutir la intersección entre ser un enfermero/ser un terapeuta en el campo de la salud mental. Método: investigación exploratoria y cualitativa, basada en una entrevista de autoevaluación realizada con diez enfermeras de un hospital psiquiátrico en Rio de Janeiro entre junio y julio de 2017. Los datos se analizaron a la luz de la Teoría de Travelbee. Resultados: Los enfermeros se consideran terapeutas por las acciones desarrolladas en la práctica de la atención de salud mental, a pesar de la fragmentación teórica de la relación interpersonal identificada en la distancia de la promoción del autoconocimiento, que es un elemento esencial en el proceso psicoterapéutico. Consideraciones finales: sobresale la fuerte relación entre el ser y el hacer de enfermería, la cual favorece el desarrollo de relaciones terapéuticas satisfactorias con la persona hospitalizada.

Descriptores: Rol del Profesional de Enfermería; Salud Mental; Terapéutica; Enfermería Psiquiátrica; Hospitales Psiquiátricos. 


\section{INTRODUCTION}

Who is the therapist in the field of mental health $(\mathrm{MH})$ practice? Is it possible to be a mental health nurse without being a therapist? According to historical data, the etymology of the term therapy comes from the Greek, therapeia, first used by Hippocrates with the meaning of providing medical care. Over time, it moved to Latin and successively to more modern languages with its meaning extended to any means or procedures used in treating the sick ${ }^{(1)}$. Therapists are professionals who apply recognized techniques for restoring people's health and quality of life ${ }^{(2)}$. In therapeutic practice, there are several possibilities in the field of care. Here, the focus is on the perspective of mental health care.

Psychotherapy is an activity open to many professional categories, including nurses. The restriction to a particular profession is absolutely contrary to science, illegal and unconstitutional ${ }^{(3)}$. This perspective was stated in the normative opinion of the Brazilian Federal Nursing Council (Portuguese acronym: COFEN) and stems from a request from the Sergipe Regional Nursing Council (Portuguese acronym: COREN-SE) that requested clarifications about nurses' competence in psychotherapy, defined as a process of self-knowledge that can improve the lives of individuals.

The focus of this study is on the theme of Mental Health therapy by considering the perspective of nurses working in this field in relation to the elements necessary for the development of therapy by nurses. Joyce Travelbee's theory ${ }^{(4)}$ was used to guide the study.

Joyce Travelbee was inspired by Hildegar Peplau, who built the theory of Interpersonal Relations. Travelbee's theory is supported by twelve assumptions, and presents the therapist nurse as one who can anchor care in human relationships, which is possible as long as sustained by empathy, rapport, trust, respect and authenticity ${ }^{(4)}$.

Compiling her theory, one realizes that commitment is essential. According to her suggestion, commitment is evident when the simple role assigned is expanded and there is a real interest in the welfare of the other. This theorist was chosen to guide the discussion because of the therapist concept apprehended from her assumptions ${ }^{(4)}$ : therapist nurses use their own body, hold a philosophical resource (scientific, artistic, sensitive and creative) to find the other and awaken/enhance the wellbeing of both the professional and the person cared for. Nursing is commonly linked to the performance of concrete procedures, such as blood pressure measurement, medication administration and dressings. The present study addresses nurses working in Mental Health, where care is provided mainly through listening and the word. We infer this leads to another stereotype, of nurses with the psychologist profile.

By proposing greater space for dialogue and expression of emotions of people cared for, some nurses report being considered by them, and even by their colleagues, as psychologists. Nurses must build new conceptions and perspectives, find a shift, some dialectic between the care performed in the body and the care guided by the word ${ }^{(5)}$, although without being stereotyped as psychologists, because subjective care should be understood as nurses' role.

These intersections encouraged our research and consequently, directed the article to the following guiding question: can nurses working in $\mathrm{MH}$ and Psychiatry be considered therapists?

\section{OBJECTIVE}

To discuss the intersection between being a nurse and being a therapist in mental health in the light of Travelbee's theoretical perspective $^{(4)}$.

\section{METHOD}

\section{Ethical aspects}

As this study involved human beings, the project was submitted to the Research Ethics Committee of the University Hospital Antônio Pedro of the Universidade Federal Fluminense. The principles of Resolution number $466 / 2012^{(6)}$ of the National Health Council were respected. For maintaining participants' anonymity, their names were replaced by codes E1, E2 ... E10.

\section{Design and period of the study}

A qualitative study was performed, which unveils little known social processes related to particular groups and enables the construction of new concepts ${ }^{(7)}$. The data collection period was between June and July 2017 through semi-structured interviews guided by the self-report technique. Self-reports are participants' answers to questions asked by the interviewer and tend have a conversational nature ${ }^{(8)}$.

\section{Study scenario}

The study scenario was a public hospital specialized in psychiatry located in the city of Rio de Janeiro. Some characteristics of the hospital make it difficult to implement the principles of the Brazilian Psychiatric Reform (RPB), for example, the rights of patients in psychological distress, as provided by law $10.216 / 2001^{(9)}$. The space is common to patients hospitalized in their first crisis and patients in recurrent readmissions, who often spend little or no family time and in community life between one hospitalization and the other ${ }^{(10)}$

\section{Source, criteria and data collection}

Participants of the study were ten nurses from the psychiatric hospital. The inclusion criterion was to act directly in the care of hospitalized people. The exclusion criterion was to be on vacation or on leave.

The semi-structured script contained the following sociodemographic items: age, sex, time since graduation, time of experience and courses taken in the area of $\mathrm{MH}$. In also included the following questions: do you consider yourself a therapist? Why?

\section{Organization and analysis of data}

Inspiration from dialectical hermeneutics, which presents three steps to be followed: ordering, classification and final analysis of data ${ }^{(11)}$. In this study, the ordering comprised the detailed organization of speeches and characterization of the interviewed subjects. The classification was the grouping of results by units with the aim to understand what was said with 
greater representativeness, from where the following categories emerged: 1 - Meanings attributed by mental health nurses to the therapeutic practice; 2 - Therapist nurse: the power. The final analysis of data is a circular movement that goes from the empirical to the theoretical and vice versa ${ }^{(11)}$. At this stage, we analyzed data and got in touch with Travelbee's Human to Human Relationship Model(4).

\section{RESULTS}

Data collection demonstrated the following profile of study participants: $100 \%$ female, aged 32 to 53 years, between nine and 29 years of time since nursing training and working time in $\mathrm{MH}$.

With respect to courses, six nurses attended postgraduate programs with residency in mental health, as well as courses on topics in this area, namely: improvement on psychiatric emergencies, alcohol and other drug policies, and psychopharmacology. Two interviewees have not taken any mental health course, although they have been working in the area for over ten years. The other specializations were pediatrics and management. Three nurses hold a master's degree, three are master's students and one is a doctoral student.

\section{Meanings attributed by Mental Health nurses to the thera- peutic practice}

The data collection through self-reports focused on the theme of mental health therapists, and statements revealed that nurses promote encounters and are constantly predisposed to perform therapeutic actions together with hospitalized people. According to nurses' perspectives, the care practice becomes possible in the act of surrender to the other. They affirmed that Mental Health care is something obligatorily produced by the act of the professional being available to the other.

\section{Therapist nurse: the potency}

Regarding therapy in Mental Health Nursing, the nurses reported how they perceive this aspect. The self-reports are shown in the Figure 1.

\section{DISCUSSION}

When asked if they consider themselves as therapists or not, the reasons and the practices that justify this consideration, all nurses participating in this study (without hesitation) stated they consider themselves as therapists because of their professional practice with people admitted to a psychiatric hospital. The statement of E8 demonstrates this role oscillates between being and doing.

The self-report of E8 is corroborated by historical data, in which female nurses are not known as women practicing their profession. Their whole person disappears behind the nurse's character ${ }^{(12)}$ and they are what they do.

The nurses interviewed brought a valuable fusion of meanings when stating that in their practice, there is no differentiation between what they say they do, and what they say they are. From supposedly therapeutic actions, nurses see themselves as therapists, although some, such as E5 and E6, have never taken any training courses in $\mathrm{MH}$ or psychiatry. This aspect can be understood by historical facts of nursing work in $\mathrm{MH}$, which is marked by the medical model of control of individuals with subordinate nursing practices that support the disciplining medical-political process. Currently, nurses are a potential and important agent of change, and this potentiality is directly related to the degree of awareness of these workers ${ }^{(13)}$.

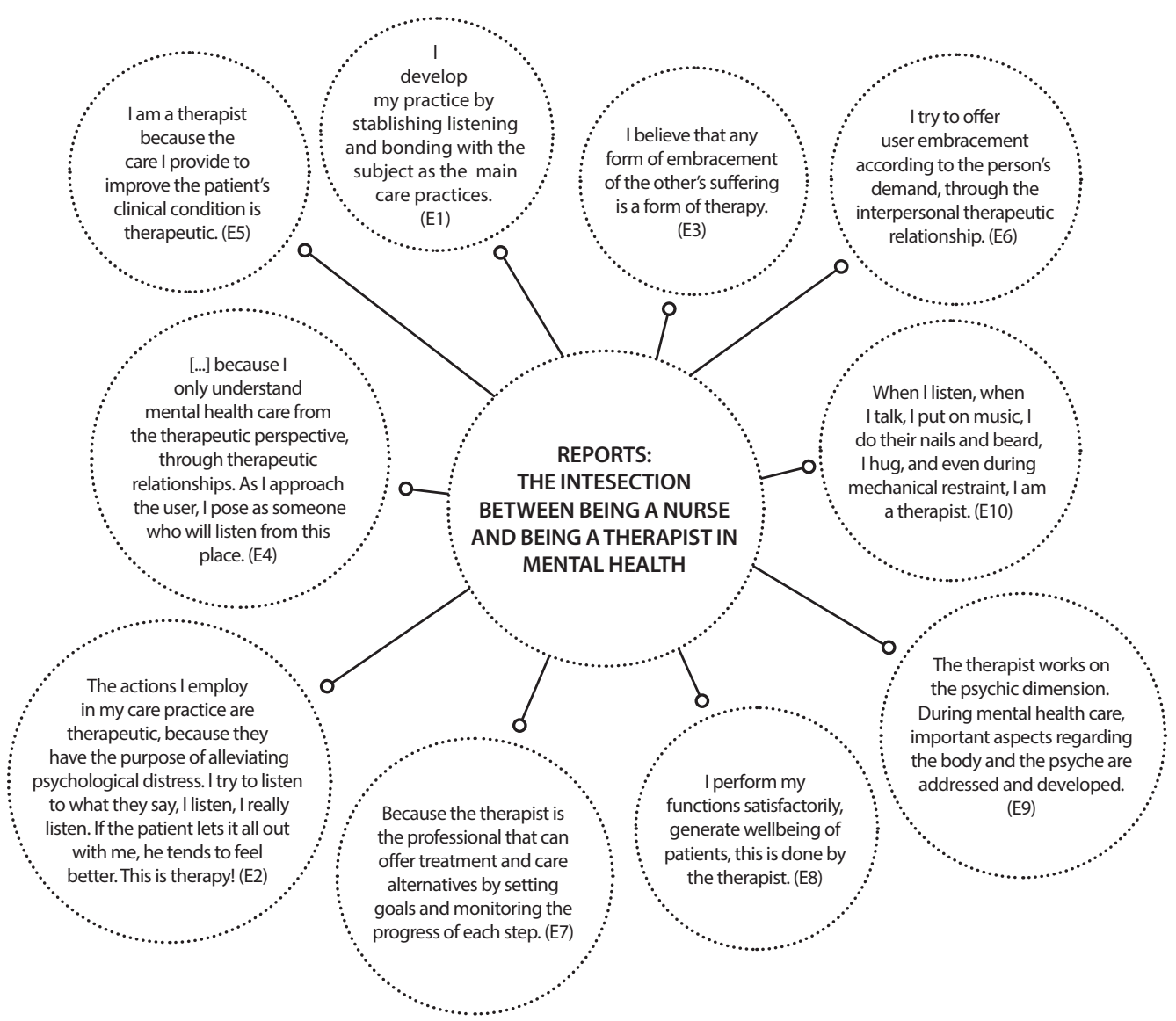

Figure 1 - Testimonials from study participants, Niterói, Rio de Janeiro, Brazil, 2017 
Theoretical deepening is essential for raising this awareness. The more aware of their personal and social condition, their role of a worker inserted in a social context and a citizen in a political system, the better able they will be to choose work tools that rescue people with mental disorders from this same subject-citizen condition ${ }^{(13)}$.

Nurse E5 mentions care as essentially therapeutic without addressing the establishment of the human to human relationship as the purpose of care, as advocated by Travelbee ${ }^{(4)}$ in her first assumption. In this sense, E10 enumerated some of her attributions as a justification for being a therapist.

Travelbee's fifth assumption states that the quality and quantity of care offered are influenced by the perception of two subjects, the nurse and the patient ${ }^{(4)}$ and the statement of E10 is restricted to the nurse. There is a "do for" and not a "do with", do for the person cared for and not do with them, which may subliminally deviate from the problem identification, according to Travelbee ${ }^{(4)}$, as a stage to be fulfilled in the encounter between these subjects, and the condition of therapist sustained by the communication established in a therapeutic relationship.

Thus, although they claim to be therapists, the manifest element in the speeches is user embracement, as explained by E3. User embracement is a necessary condition for establishing a therapeutic relationship. Although it does not appear with this nomenclature in Travelbee's model(4), the elements brought, such as rapport for creating a harmonious feeling based on the knowledge and uniqueness of individuals, the ability to stand still and experience the other as a human being, and the true ability to care for the other, are related to the user embracement referred by nurses.

Although essential, user embracement needs to be applied in tune with other elements, such as empathy, trust and respect. Only user embracement alone does not configure therapy itself for achieving a psychotherapeutic relationship ${ }^{(10)}$. Such thinking can be confirmed by E2, which leads us to a question about what to do with listening. The inquiry is anchored in the concept of therapist nurses as those who use their own body and hold philosophical resources (scientific, artistic, sensitive and creative) for finding the other and awakening/enhancing the wellbeing of both the professional and the person cared for.

Making oneself available to other sand listening to their supplications and lamentations, achievements and defeats, loves and losses, delusional ideas and daydreams certainly does not seem an easy task. However, this is working substrate for preparing the therapy site. This is a provocation that calls for reflection. This concept is supported by the debate in the literature about a therapeutic action for subjects and their form of suffering by treating the therapeutic action of:

Each one has a more individualized structure [...] If, despite the standardization imposed by uniforms, are made flowers, small printed marks that declare uniqueness, this is therapeutic. In short, these are ways of emptying or making holes in the universal and generalizing discourse of the institution ${ }^{(8)}$.

Practices described above certainly translate care and we understand nurses represent it. User embracement may be enough when performing a procedure, such as passing a bladder catheter before a surgery. After user embracement, even if the individual undergoes an invasive procedure, there is possibility of a therapeutic procedure. Although technically effective, a therapeutic procedure of manual intervention does not determine a therapeutic relationship in all aspects of care, nor guarantees that nurses are therapists from the perspective of mental health.

The speeches of nurses E1, E2, and E6 address the basic components of establishing therapeutic communication, such as empathy, trust, and mutual respect ${ }^{(14)}$.

The term therapeutic relationship was created in the Mental Health context, where assistance values relationships of help, group meetings and interpersonal relationship, and is used in a comprehensive and individualized way to highlight the potential of individuals in psychological distress and recover their autonomy ${ }^{(15)}$. However, being a therapist is not limited to this relationship.

Nurses should conduct the biopsychosocial clinical care of subjects in psychological distress, assist them throughout their journey and in the construction of a connection with treatment ${ }^{(16)}$. This brings the understanding that practices self-reported in the interviews are more deeply anchored in the encounter with subjects than in therapy, as exposed in the speech of E4 (shown in the figure of this article).

The difference between a therapist and a psychotherapist is extremely relative. Although COFEN regulations 002/2012 ${ }^{(3)}$ mention the requirement for a psychoanalysis course for nurses being recognized as therapists, in fact, they can play a psychotherapeutic role. We make this statement because generalist training includes the study of Nursing theories, among which, the theories that guide nurses on the nurse-patient therapeutic interpersonal relationship. Hildegar Peplau and Travelbee offer the arsenal that can be employed by nurses.

As stated by E4, those willing to make changes in health care by reversing work technologies so that relational technologies are the center of their practice, must first precisely understand how care is given and what happens between professionals and users during their encounter ${ }^{(17)}$. Still explaining this encounter:

When we find an outer body that does not match ours (that is, which does not establish a relationship with ours), everything happens as if the power of that body were opposed to our power by operating a subtraction, a fixation: in this case, we say that our power to act is diminished or blocked, and the corresponding passions are of sadness. But on the contrary, when we find a body that suits our nature and establishes a relationship with ours, we would say its potency is added to ours: the passions affecting us are of joy, our power of action is enlarged or favored ${ }^{(18)}$.

In daily health care, are built meetings that trigger care in a demand that is sometimes perceived and at other times announced. Care can become therapeutic as long as it produces affectations of joy, not sadness ${ }^{(19)}$. This includes affectations resulting from simple, routine activities, although elementary and necessary.

There is no guarantee a standardized conduct will be therapeutic for those cared for. The power of each encounter cannot be measured in advance. The composition and consequence of a conduct in which professionals intend to be therapeutic will depend on their power to be affected at the moment the bodies meet, that is, the production of affectations ${ }^{(19)}$.

The fact is, no one has so far determined what the body can do, that is, so far, experience has taught nobody what the body 
- exclusively by the laws of nature while considered only bodily, without being determined by the mind - can and cannot do ${ }^{(19)}$.

The encounter of bodies, as a production of affectations, cannot be standardized. Affection, that is, the deconstruction of indifference, occurs during the care process. The multiplicity exists in each subject and in the singularities of different encounters ${ }^{(19)}$.

Psychotherapy is a care intervention, not a profession, and considered an activity open to various professional categories, such as Psychologists, Pedagogues, Doctors, Nurses, Teachers, Engineers, Dentists, Lawyers, Social Workers, Theologians, Pastors, Priests, Accountants, and others, as long as a postgraduate program in psychoanalysis has been completed ${ }^{(3)}$. Although this specific training may represent qualification, becoming a therapist transcends this fact. Similarly, not everyone who undergoes specific training in psychoanalysis becomes a therapist, as this requires internal availability, self-knowledge, and the ability to use other personal resources such as sensitivity, intuition, creativity, and art.

We consider the reports mentioning the intensification of therapeutic activities close to Travelbee's assumptions as a rehearsal to being a therapist ${ }^{(4)}$. According to the seventh principle, for establishing a therapeutic relationship, it is necessary to go beyond the roles of nurse and patient. First and foremost, both are people with life histories, and individual and unique fears and longings. The ninth principle states that relationships occur through communication ${ }^{(4)}$ and requires nurses' exercise for achieving resources for this practice. Communication is understood as something that allows the expression of care and psychosocial bond. It is fed by the mixture of cognitive and affection interfaces.

When E8 mentioned that her attitude as a therapist involved generating wellbeing, we understand this search can go beyond the nurse and patient roles ${ }^{(4)}$. Nurses should perform their professional duties linked to the programs built within the Brazilian Psychiatric Reform process, which implies creating new spaces for nursing care ${ }^{(20)}$, and free themselves for new performances that overcome the determined roles. The creation of new spaces for care and interaction is a strategy to expand the possibilities of nurses acting as integral therapists.

An important aspect of therapists' role is helping patients to become aware of unconscious patterns expressed in their nonverbal conduct so that in the end, they can gain a sense of mastery and understanding of what is being repeated in one relationship after the other ${ }^{(21)}$.

In the self-report of interviewees, the aspect of helping others to become aware is not perceived, although some behaviors are close to the concept as we understand it. For example, E9 stated the therapist is the one who develops care with a view of the body and the psyche. The interdisciplinary perspective is essential for nurses' production of care that incorporates the relationship and inseparability of the body-mind binomial. Having a formation with interdisciplinary knowledge is also fundamental for any professional playing the psychotherapeutic role, that is, the integral view of the subject along with other fundamentals guiding the therapeutic relationship.

In face of the availability to work with the other, E9 approaches Travelbee's tenth assumption: "a nurse can help people to find meaning in their illness and deal with it"(4). In the same direction,
E7 considers herself a therapist for offering treatment alternatives and monitoring the progress of subjects' health status. This follow-up should be associated with psychosocial care guidelines, regardless of the nurse's training, and include user embracement, therapeutic workshops and individualized care ${ }^{(22)}$.

The aim is that nurses offer user embracement, observe, provide care and affection, and minimize the suffering of hospitalized people. However, something is still lacking for considering them therapists, because psychotherapy is a self-knowledge process. During this process of self-discovery, people will come to know themselves, perceive their personal characteristics, learn to deal with their difficulties, conflicts and limitations, will also perceive their thoughts, feelings and behaviors, and be able to act on them in a milder or more positive way ${ }^{(3)}$.

What is lacking can be clarified by nurses' continuing education. Knowledge favors the establishment of therapeutic relationships, since the more people know themselves and allow to be known by others, the more aware of their actions and the more satisfying interpersonal relationships they will attain ${ }^{(23)}$.

In this article, this is one of the issues that allows us to differ from the interviewees and tell them that although appreciable and effective, user embracement does not give nurses the title of therapist. The core of therapy is self-knowledge, which is not restricted to user embracement, which in turn, prioritizes listening and caring for subjects with demands beyond the body that have psychological, social, family, and community nuances ${ }^{(24)}$.

Then, there is the possibility and potentiality of nurses putting themselves in a relationship of equality, human-to-human ${ }^{(5)}$ and in this uniqueness, discovering with instruments such as poetry, music and embroidery, what potencies nurses bring with themselves, and thus, they affect themselves and affect the other. That is a situation of nurses being therapists.

In order to contemplate a psychotherapeutic intervention in Nursing, the following are needed: comprehensive theoreticalpractical parameters that meet the particularities of the different fields of care; not being conditioned to a specific line of thought; understanding and being available to people's different needs; using the therapeutic relationship as a vehicle to put the assistance relationship into effect ${ }^{(25)}$.

When defending they are therapists, interviewed nurses highlighted how therapeutic their attitudes are, even in a hospitalization scenario in disagreement with the open-door services in the light of the Brazilian Psychiatric Reform. As stated in the scenario description, the hospital under study does not favor the establishment of therapeutic relationships, nor the exercise of the therapist role by nurses. These data reveal elements indicative of availability and the capacity to surrender oneself to the other. A rehearsal.

As it is (and should be) unfeasible to predict the modes of affectation of bodies, when being available to an interpersonal relationship without judgments, professionals will face their own singularities and those of hospitalized people. There are also singularities produced in the encounter itself, in the act: the permanent rehearsal of encounters in which subjectivities are not repeated.

Thus, nurses who try to establish a person-to-person relationship, even with the best of intentions, have no certainty beforehand 
that an affectation of joy will be produced. An intentionality does not determine the result of the affectation of bodies ${ }^{(19)}$. The intention interferes but does not determine it. What we problematize is that by seeking the psychotherapeutic position, nurses will not always produce happy affectations.

One must keep in mind that the therapeutic relationship generates lifelines, but it also includes encounters that diminish the will of power, reduce the power of life, that is, can produce what Espinoza ${ }^{(19)}$ called death lines ("death of the power of life"). Using examples is always risky, but we dare: a nurse can silence the desire for life, the desire for power of a person hospitalized in a psychiatric hospital because the nurse's presence is already an undeniable and fateful announcement that one is ill or that people consider him/her psychically ill. This is an example, not a rule. Like this one, other examples may arise by keeping in mind that producing affectations of joy or sadness, producing life and death lines, producing care and less will to live are not dualistic things. No matter how good the nurse's intentions are, the affectation of bodies occurs spontaneously and escape the psychotherapist's expectations.

For Travelbee, nurses use themselves, make therapeutic use of the self, because they are affected and affect the behavior, feeling and thinking of the other, and to this end, they need to be aware of their values, beliefs and feelings. Nurses combine the intellect and emotion in search for a meaning for human experiences, and bring the ability to love as a possibility to face reality and discover the purpose of life ${ }^{(4)}$.

If the therapist's place involves so many concrete and subjective nuances and occurs at the exact moment of the encounter, then, professionals must increasingly know themselves, their potentialities, limitations, doubts, their fears, their dreams, their history, and their specific sensitivity in order to produce free subjectivities when the bodies are affected.

Just as aspects of the psychotherapist, the patient and the quality of the relationship between them are among the factors contributing to the effectiveness of psychotherapies ${ }^{(26)}$, nurses who wish to become therapists must invest in themselves. Or those who wish to act in a therapeutic way, must get involved with user embracement that includes ethics/aesthetics/politics: ethics in terms of commitment to the recognition of others, in the attitude of embracing them in their differences; aesthetics, because it brings to everyday relationships and encounters, the invention of strategies contributing to dignify life and the living; and politics, because it implies the collective commitment of getting involved in being with and empowering protagonisms and life in the different encounters ${ }^{(24)}$.

As the encounter in the production of affections is something intrinsic to the psychotherapeutic relationship, and based on the Travelbee Nursing model, nurses must develop their self-knowledge. This aspect is a condition for any professional performing this role and the psychotherapeutic process in an announced way. Travelbee reinforces the need for nurses developing their selfknowledge and perception of their relationship with each person permanently. For this reason, from nurses' self-reports that point out the development of important steps for the psychotherapeutic relationship, and based on assumptions of the current Nursing theory, we affirm that the nurses studied do not play the role of the nurse as a psychotherapist or are unsure about it, because they do not include self-knowledge as an indispensable aspect.

This discussion about nurses not developing all the necessary aspects for psychotherapeutic performance came from a reflection based on Travelbee's own Nursing model. That is, the study results were not evaluated with use of parameters external to nursing. Hence the suggestion to a greater emphasis on this theory in teaching and training spaces of professional nurses, because this theoretical arsenal forms the axis of guidance for nurses' psychotherapeutic performance.

We consider that specialization in psychoanalysis can be both productive and obstructive. If this is a prerequisite for naming nurses as psychotherapists, it will minimize the psychotherapeutic function offered in nursing education, which would have negative consequences. On the other hand, clinical and institutional supervision and some kind of psychotherapeutic process should corroborate this formation, because the possibilities of selfknowledge offered by these processes have not been valued in the daily routine of nurses working in mental health.

A reason for nurses not reporting their own therapeutic process or self-knowledge as a condition to play the psychotherapeutic role may be the negligence of all involved, because they do not realize their actions intersect with patients' psychotherapy. Assuming the psychotherapeutic role of nurses requires investment of nurses themselves and of the multidisciplinary team, who need to understand the place of nurses in mental health. Both should consider that the demands for clinical-institutional supervision and for a therapeutic process of nurses are the same as those of any member of the mental health team.

Besides the basis of nursing theory, clinical-institutional supervision and nurses'therapeutic process, some technologies also include psychotherapeutic approaches by nurses, namely: using the Operative Group technique created by Pichon-Rivière; psychodrama; empowerment groups; mediation of mutual support groups; sociodrama and other group techniques that provoke the revision of roles, meanings and emotions present in social relations ${ }^{(27)}$. Nurses study and implement therapeutic groups in all their areas of expertise and have relevant training for this. By using the systematized knowledge of the various groups created by psychiatry and mental health scholars that involve the psychic, social and emotional functions of patients, nurses have one more care tool that if used properly, can inevitably become a psychotherapeutic action.

\section{Limitations of the study}

A limitation of the study was interviewing only nurses without investigating what do people they care for consider about this issue that directly affects them. This aspect should be considered in future studies. Another limitation was the study scenario, the psychiatric hospital, because its structure makes it difficult to establish therapeutic relationships.

\section{Contributions to the area of Nursing, health or public policy}

A contribution to the health care practice was that the study encouraged a reflection about the need to expand the sources of each being, to transcend the academic space and expand fully 
and sensitively, despite political events and daily difficulties, in order to establish a therapeutic relationship, realize and recognize being a nurse therapist.

\section{FINAL CONSIDERATIONS}

The study demonstrated that "being" and "doing" are unison elements in the praxis of mental health nurses and user embracement is a support element of nursing care.

The study showed there is no demerit in the fact that mental health nurses are not considered therapists because of the regulation requiring a psychoanalysis specialization for the practice. For being a therapist in fact, nurses must expand their self-knowledge and have human, artistic and sensitivity skills that allow them to be available to others in ways that they affect others and affect themselves.
When working in mental health, therapists are not playing a previously given role, they only exist in the act. Therapists are born in the encounter and happen at the instant of the production of subjectivities that occur in the affectation of bodies, in the alterity resulting from the sensitive being.

The perspective that psychotherapeutic performance lies in psychoanalysis education is reductionist. Data showed that the therapy permeates multiple nuances not restricted to the operant mode of such specialization, as demonstrated by the several perspectives mentioned by nurses regarding their therapeutic praxis.

We understand that a nurses' training for the effective exercise of therapeutic practice requires more than a title of specialized training in psychoanalysis. It requires an extended human formation that includes not only rational components, but above all, the sensitive, intuitive and artistic aspects present in every assistance relationship.

\section{REFERENCES}

1. Rezende JM. Terapia, terapêutica, tratamento. Rev Patol Tropic [Internet]. 2010 [cited 2017 Sep 16];39(2):149-50. Available from: https:// revista.iptsp.ufg.br/up/63/o/2010_39_2_149_150.pdf

2. Ferreira ABH. Dicionário Aurélio [Internet]. 2017 [cited 2017 Sep 29]. Available from: https://dicionariodoaurelio.com/

3. COFEN. Parecer normativo nº02/2012. Dispõe sobre a competência do enfermeiro psicoterapeuta de base analítica.

4. Travelbee J. Intervención en enfermeria psiquiatrica. Carvejal: Cali, 1979.

5. Kurimoto TCS, Penna CMM, Nitkin DIRK. Knowledge and practice in mental health nursing care. Rev Bras Enferm [Internet]. 2017 [cited 2017 Oct 02];70(5):973-80. Available from: http://dx.doi.org/10.1590/0034-7167-2016-0343

6. Conselho Nacional de Saúde (BR). Resolução n 466 de 12 de dezembro de 2012. Dispõe sobre aspectos éticos em pesquisas com seres humanos.

7. Medeiros SLA, Araújo ABP, Valença CN, Germano RM. Metodologia da pesquisa qualitativa na saúde. Interface (Botucatu) [Internet]. 2012 [cited 2017 Oct 05];16(41):579-81. Available from: http://dx.doi.org/10.1590/S1414-32832012000200022

8. Santos JLG, Erdmann AL. Governance of professional nursing practice in a hospital setting: a mixed methods study. Rev Latino-Am Enfermagem [Internet]. 2015 [cited 2017 Oct 09];23(6):1024-32. Available from http://dx.doi.org/10.1590/0104-1169.0482.2645

9. Ministério da Saúde (BR). Lei no 10.216 de 6 de abril de 2001. Dispõe sobre a proteção e os direitos das pessoas de transtornos mentais e redireciona o modelo assistencial em saúde mental.

10. Silveira LHC, Rocha CMF, Rocha KB, Zanardo GLP. The other side of the revolving door: community support and mental health. Psicol Estud [Internet]. 2016 [cited 2017 Sep 18];21(2):325-35. Available from: http://www.redalyc.org/articulo.oa?id=287147424014

11. Polit DF, Beck CT. Fundamentos de pesquisa em enfermagem: avaliação de evidências para a prática da enfermagem. 7.ed. Porto Alegre: ARTMED, 2011.

12. Ramos DKR, Mesquita SKC, Galvão $M C B$, Enders BC. Paradigmas da saúde e a (des)valorização do cuidado em enfermagem. Enferm Foco [Internet]. 2013[cited 2017 Sep 18];4(1):41-4. Available from: http://revista.portalcofen.gov.br/index.php/enfermagem/article/view/501/0

13. Souza MC, Afonso MLM. Saberes e práticas de enfermeiros na saúde mental: desafios diante da Reforma Psiquiátrica. Rev Interinst Psicol[Internet]. 2015[cited 2017 Sep 18];8(2):332-47. Available from: http://pepsic.bvsalud.org/pdf/gerais/v8n2/v8n2a04.pdf

14. Stefanelli MC, Carvalho EC. A comunicação nos diferentes contextos da enfermagem. 2ed. São Paulo: Manole, 2012.

15. Elias ADS, Oliveira FA, Tavares CMM, Muniz MP, Abrahão AL, Silva LSAH. Sociopoética: laços entre arte e educação. Rev Pró-UniverSUS [Internet]. 2016 [cited 2017 Oct 02];7(2):39-42. Available from: http://editorauss.uss.br/index.php/RPU/article/download/350/528

16. Cavalcanti PCS, Oliveira RMP, Caccavo PV, Porto IS. Nursing care centers in psychosocial care. Cienc Cuid Saude[Internet]. 2014[cited 2017 Sep 23];13(1):111-9. Available from: www.periodicos.uem.br/ojs/index.php/CiencCuidSaude/article/viewFile/.../pdf_120

17. Vianna D. Terapia Expressiva: a arte do afeto colorindo um hospital. Niterói: Editora UFF, 2014.

18. Deleuze G. Espinosa, filosofia prática. São Paulo: Escuta, 2002.

19. Espinoza, B. Ética: Tradução de Tomaz Tadeu. Belo Horizonte: Autêntica Editora, 2009.

20. Maftum MA, Pagliace AGS, Borba LO, Brusamarello T,Czarnobay J. Changes in professional practice in the mental health area against Brazilian psychiatric reform in the vision of the nursing team. Rev Pesqui: Cuid Fundam[Internet] 2017 [cited 2017 Oct 22];9(2):309-14. Available from: http://www.seer.unirio.br/index.php/cuidadofundamental/article/view/3626/pdf 
21. Carvalho C, Godinho LR, Ramires VRR. Child Psychotherapeutic Process: Analysis Based on the Child Psychotherapy. Q-Set Q-Set. Temas Psicol[Internet] 2016 [cited 2017 Jul 24];24(3):1153-67. Available from: http://dx.doi.org/10.9788/TP2016.3-19

22. Pessoa JMJ, Sales CF, Santos RCF, Fortes VA, Miranda FAN. Nursing and the deinstitutionalization process in the mental health scope: integrative review. Rev Pesqui: Cuid Fundam [Internet] 2017. [cited 2017 Out 02];9(3):893-8. Available from: http://www.seer.unirio.br/index. php/cuidadofundamental/article/view/4475/pdf

23. Silva AA, Terra MG, Gonçalves MO, Souto VT. Self-care among Nursing Professionals: an integrative review of Brazilian dissertations and theses. Rev Bras Ciênc Saúde [Internet]. 2014[cited 2017 Sep 23];18(4):345-52. Available from: https://periodicos.ufpb.br/index.php/rbcs/ article/view/15263

24. Ministério da Saúde (BR). Acolhimento na gestão e o trabalho em saúde. 2016.

25. Sampaio F, Sequeira C, Lluch-Canut T. A intervenção psicoterapêutica em enfermagem de saúde mental: Conceitos e desafios. Rev Port Enferm Saúde Mental [Internet]. 2014, n.spe1 [cited 2017 Sep 30];(no.spe1)103-108. Available from: http://www.scielo.mec.pt/pdf/rpesm/ nspe1/nspe1a17.pdf

26. Peixoto EM. Vera case: psychotherapist interventions and therapeutic alliance. Trends Psychol [Internet] 2016[cited 2017 Jul 24];24(4):120515. Available from: http://dx.doi.org/10.9788/TP2016.4-02Pt

27. Stefanelli MC, Fukuda IMK, Arantes EC. Estratégias de Comunicação Terapêutica. Enfermagem Psiquiátrica em suas dimensões assistenciais. Barueri: Manole, 2008. p.267-280. 